\title{
Analysis of the Determinants of Female Genital Mutilation Practices in Senegal: A Secondary Analysis of the 2018 DHS
}

\author{
Ndeye Mareme Sougou ${ }^{1,2, *}$, Jean Baptiste Niokhor Diouf ${ }^{3}$, Oumar Bassoum ${ }^{1,2}$, Ibrahima Seck ${ }^{1}$ \\ ${ }^{1}$ Department of Preventive Medicine and Public Health, Faculty Medicine, University Cheikh Anta Diop, Dakar, Senegal \\ ${ }^{2}$ Institute of Health and Development, University Cheikh Anta Diop, Dakar, Senegal \\ ${ }^{3}$ Hospital Roi Baudoin, Faculty Medicine, University Iba Mar Diop, Dakar, Senegal
}

\section{Email address:}

nmsougou@hotmail.com (N. M. Sougou), jeanniokhor@gmail.com (J. B. N. Diouf), bassoum.oumar@gmail.com (O. Bassoum), ibouseck@yahoo.fr (I. Seck)

${ }^{*}$ Corresponding author

\section{To cite this article:}

Ndeye Mareme Sougou, Jean Baptiste Niokhor Diouf, Oumar Bassoum, Ibrahima Seck. Analysis of the Determinants of Female Genital Mutilation Practices in Senegal: A Secondary Analysis of the 2018 DHS. Central African Journal of Public Health.

Vol. 7, No. 3, 2021, pp. 121-126. doi: 10.11648/j.cajph.20210703.15

Received: April 30, 2021; Accepted: May 21, 2021; Published: May 31, 2021

\begin{abstract}
Introduction: Female genital mutilation (FGM), also known as female genital cutting or circumcision, threatens the health and well-being of millions of girls, women, and their children around the world. In Senegal, FGM practices persist despite numerous interventions. This study aims to analyze the determinants of FGM in Senegal. Methods: This article uses data from the 2018 Senegal Demographic and Health Survey (DHS), a nationally representative survey of 9413 women aged 15-49 years. In the descriptive analysis, variables were presented in terms of frequency and percentage of data. The significance level was set at 5 , and $95 \%$ confidence intervals (CIs) were used. Variables with $p$ values less than 0.25 in the bivariate analysis were selected for multivariate analysis. The dependent variable was a composite variable generated from 3 DHS variables that described the types of post-FGM genital lesions that exist in women. The analysis was performed using STATA/SE 17. Results: The prevalence of FGM is $17.14 \%$. Eleven-point fifty-two percent (11.52\%) or 999 women believe that FGM is a religiously recommended practice. Ninety-nine percent (993) of these women were Muslim ( $\mathrm{p}=0.0017)$. Fifteen-point thirty-nine percent $(15.39 \%$ ) or 1,334 women think it is a practice that should continue to be practiced and $80.59 \%$ (or 6,988 women) think it should be stopped. The protective factors for the occurrence of FGM were female empowerment (high level of education of the woman (primary ajOR $=0.64[0.50-0.83]$ and secondary ajOR=0.43 $[0.32,0.57]$ ) and the fact that the head of the family was a woman ajOR (0.75 [0.59-0.97]); belonging to the central region of Senegal (Diourbel, Kaolack, Thiès, Louga and Fatcick) and Christian religion (ajOr=0.05 [0.02-0.13]). The risk factors for female genital mutilation in Senegal were ethnicity and belonging to certain regions in the northeast and southeast of Senegal (Tambacounda, Matam, Kedougou). Conclusion: This study showed that FGM practices are still persistent in Senegal. This study underlined that the empowerment of women would allow the fight against FGM. Health interventions should be multisectoral, involving the education sectors with a strong investment in girls' education and retention.
\end{abstract}

Keywords: Female Genital Cutting, Determinants, Senegal

\section{Introduction}

Female genital mutilation (FGM), also known as female circumcision, threatens the health and well-being of millions of girls, women and their children around the world [1]. Female genital mutilation has no health benefits and is known to cause serious short- and long-term damage to the physical and psychological health of victims [2]. Thus they are at the origin of obstetrical consequences which can engage the vital prognosis of the woman during the delivery [3]. Over 200 million girls and women alive today have been cut in 30 countries in Africa, the Middle East and Asia where FGM is concentrated [4]. Africa still bears the greatest burden. Female genital mutilation of any kind has been recognized as a harmful practice and a violation of the human rights of girls 
and women [5]. By 2030, the Sustainable Development Goals through Goal 5 in its indicator 5.3.2 addresses the problem of FGM by insisting on a reduction of the "Proportion of girls and women aged 15-49 years who have undergone female genital mutilation/cutting, by age" [6]. In Senegal, since the 1970s, excision has been combated by the Senegalese authorities through awareness programs. Since 1999, the practice is legally repressed and excisers are regularly brought to justice and sentenced to a minimum of 6 months in prison, at least for example [7]. However, it is noted that over the years, despite the many health interventions made, there is a slight decline in FGM practices in Senegal [7].

Studies have been conducted on FGM in Senegal, but few have focused on the determinants of FGM practices. This study aims to analyze the determinants of FGM in Senegal.

\section{Methods}

\subsection{Type of Study}

This is a descriptive cross-sectional study with an analytical purpose.

\subsection{Data}

This article uses data from the 2018 Senegal Demographic and Health Survey (DHS), a nationally representative survey of 9413 women aged 15 to 49 years. The DHS-Continuous 2018 sample is representative at the national level, at the regional level, and for urban and rural settings. The sample was drawn stratum by stratum. Thus, the sample is based on a stratified, two-stage area sample drawn in accordance with the DHS sampling methodology [8]. At the first level, 400 clusters (primary sampling units [PSUs]) were drawn from the list of enumeration areas (EAs) established during the 2013 General Census of Population and Housing, Agriculture, and Livestock (RGPHAE), using a systematic draw with probability proportional to size, with the PSU size corresponding to the number of households [9]. A count of households in each of these clusters provided a list of households from which a sample of 22 households per cluster waś drawn, in the second stage, from both urban and rural areas with systematic equal probability. A total of 8,800 households (4,092 urban and 4,708 rural) were selected.

Data were collected using four questionnaires - Household, Female, Male and Biomarkers. The Female Individual Questionnaire was used to record information from females aged 15-49 years who were residents or visitors the night before the survey. The Individual Record (IR) file was used for the analysis.

The dependent variable is a composite variable generated from 3 DHS variables that describe the types of post-FGM genital lesions that exist in the woman interviewed. The lesion was described by the woman and is not observed by a health provider. These variables are: variable 1: women who have parts of flesh removed from the genital area coded in 3 modalities yes, no, don't know; variable 2: women who have lesions in the genital area that is just nicked without removing flesh with 3 modalities yes, no, don't know; and variable 3 women who have closure of the genital area sewn with 3 modalities yes, no, don't know. The generated variable is dichotomous with 2 modalities "yes" and "no". "Yes" for all women presenting at least one of the above-mentioned lesions.

The independent variables: the socio-demographic factors were place of residence: this was dichotomized as "urban" or "rural"; the woman's level of education; the gender of the head of the household; the household's level of wealth: the wealth index, a measure of relative economic well-being based on household assets, was categorized into quintiles (lowest, second, middle, fourth, highest) and derived from the wealth score, religion, ethnicity, and region of residence.

\subsection{Statistical Analysis}

The analysis was performed using STATA/SE 17 software. As mentioned above in the data source section, a two-stage sampling design was adopted. To account for the multi-stage sampling design of the survey, all data were weighted to account for disproportionate sampling and non-response. In the descriptive analysis, variables were presented in terms of frequency and percentage of data. Comparisons between groups were made using the Chi 2 test. The significance level was set at 5, and 95\% confidence intervals (CIs) were used. Variables with $p$ values less than 0.25 in the bivariate analysis were selected for multivariate analysis [10]. To assess the factors associated with the existence of female genital mutilation, a multivariate logistic analysis was performed to adjust for the effect of confounders. Adjusted odds ratios (ORa) were calculated with their $95 \%$ confidence intervals. To manage complex sampling (multistage sampling, weighting, and stratification), variables for identifying weights, strata, and primary sampling units (PSUs) were defined before using SVY (STATA survey prefix).

\section{Ethical Approval}

This study is a secondary analysis of data from the DHS conducted in Senegal in 2018. The 2018 Demographic and Health Survey (DHS) in Senegal was approved by the National Ethics Committee (NEC). The survey was also approved by ICF's Institutional Review Board. Informed consent was obtained from all participants in writing.

\section{Results}

\section{Prevalence of FGM}

The prevalence of FGM is $17.14 \%$ (see Table 1 ). Most of the women have a mutilation of a part of the reproductive system with $60 \%, 29.39 \%$ of women have Genital area just nicked without removing any flesh et $6.88 \%$ des femmes ont une infibulation (voir table 1). 
Table 1. Prévalence des MGF au Sénégal en 2018.

\begin{tabular}{lll}
\hline Female Genital Mutilation & Frequency n=9414 & Percentage\% \\
\hline Yes & 1617 & 17.18 \\
No & 7797 & 82.82 \\
Type de FGM & & \\
Flesh removed from genital area & $\mathrm{n}=2195$ & 60.96 \\
yes & 1338 & 25.80 \\
no & 566. & 13.24 \\
don't know & 291. & \\
Genital area just nicked without removing any flesh & $\mathrm{N}=857$ & 29.39 \\
yes & 252. & 38.79 \\
no & 333. & 31.81 \\
don't know & 273. & \\
Genital area sewn closed & $\mathrm{n}=2196$. & \\
yes & 151. & 8.88 \\
no & 1838. & 9.41 \\
don't know & 207. & \\
\hline
\end{tabular}

Table 2. Distribution of FGM according to socio-demographic characteristics.

\begin{tabular}{|c|c|c|}
\hline & Frequency $n=1617$ & Percentage $\%$ \\
\hline \multicolumn{3}{|l|}{ Woman highest educational level } \\
\hline no education & 856 & 9.097 \\
\hline primary & 360 & 3.823 \\
\hline secondary & 352 & 3.74 \\
\hline higher & 49 & 0.5158 \\
\hline \multicolumn{3}{|l|}{ Wealth index } \\
\hline poorest & 452 & 4.8 \\
\hline middle & 287 & 3.052 \\
\hline richer & 324 & 3.438 \\
\hline richest & 272 & 2.882 \\
\hline \multicolumn{3}{|l|}{ Region } \\
\hline Dakar & 442 & 4.7 \\
\hline ziguinchor & 99 & 1.05 \\
\hline diourbel & 99 & 0.0761 \\
\hline tambacounda & 138 & 2.009 \\
\hline kaolack & 189 & 0.9057 \\
\hline thies & 85 & 1.02 \\
\hline louga & 11 & 0.1162 \\
\hline fatick & 12 & 0.1314 \\
\hline kolda & 156 & 1.662 \\
\hline matam & 189 & 2.012 \\
\hline kaffrine & 17. & 0.1839 \\
\hline kedougou & 56 & 0.594 \\
\hline sedhiou & 118 & 1.256 \\
\hline \multicolumn{3}{|l|}{ Type of place residence } \\
\hline rural & 820 & 8.707 \\
\hline urban & 797 & 8.468 \\
\hline \multicolumn{3}{|l|}{ Religion } \\
\hline muslim & 1605 & 17.05 \\
\hline chistiane & 10 & 0.1074 \\
\hline \multicolumn{3}{|l|}{ Ethnicity } \\
\hline wolof & 19 & 0.1792 \\
\hline poular & 893 & 9.487 \\
\hline serer & 4 & 0.0462 \\
\hline mandingue/ soce & 250 & 2.661 \\
\hline diola & 134 & 1.424 \\
\hline soninke & 92 & 0.977 \\
\hline senegalese ethnicity & 109 & 1.157 \\
\hline not senegalese & 117 & 1.244 \\
\hline \multicolumn{3}{|l|}{ sex of household head } \\
\hline male & 1205 & 12.8 \\
\hline female & 412 & 4.378 \\
\hline
\end{tabular}


Distribution of FGM according to socio-demographic characteristics

The prevalence of FGM is higher among women without education (9\%). The regions with the highest prevalence are Dakar (4.7\%), Tambacounda (2\%), Sedhiou (1.2\%) and Matam (2\%). Women of the Muslim religion are the most concerned (17.05\%). The Poular ethnic group is the most represented $(9.49 \%)$. FGM is more common among women living in a house where the head of the household is a man (12.8\%). (see Table 2).

Women's knowledge and opinions about FGM
Women who had heard of FGM represented $90.66 \%(8,535)$ of the women.

Eleven-point fifty-two percent $(11.52 \%)$ or 999 women thought that FGM was a religiously recommended practice. Ninety-nine percent (993) of these women were Muslim $(\mathrm{p}=0.0017)$.

Fifteen-point thirty-nine percent $(15.39 \%)$ or 1,334 of the women thought that it was a practice that should continue to be performed and $80.59 \%$ (6,988 women) thought that it should be stopped.

Table 3. Factors associated with female genital mutilation in Senegal.

\begin{tabular}{|c|c|c|c|}
\hline FGM & Odds ratio & [95\% conf. interval] & $\mathbf{P}>\mathbf{t}$ \\
\hline \multicolumn{4}{|c|}{ Woman highest educational level } \\
\hline No education & 1 & & \\
\hline Primary* & 0.64 & {$[0.50-0.82]$} & 0.001 \\
\hline Secondary* & 0.43 & {$[0.32-0.57]$} & 0.000 \\
\hline higher & 0.54 & {$[0.24-1.18]$} & 0.123 \\
\hline \multicolumn{4}{|l|}{ Wealth index } \\
\hline Poorest & 1 & & \\
\hline poorer & 0.92 & {$[0.67-1.25]$} & 0.593 \\
\hline middle & 0.90 & {$[0.63-1.28]$} & 0.564 \\
\hline richer & 0.87 & {$[0.55-1.36]$} & 0.529 \\
\hline richest & 0.68 & {$[0.36-1.32]$} & 0.255 \\
\hline \multicolumn{4}{|l|}{ Region } \\
\hline Dakar & 1 & & \\
\hline Ziguinchor & 1.16 & {$[0.63-2.14]$} & 0.622 \\
\hline Diourbel* & 0.05 & {$[0.02-0.14]$} & 0.000 \\
\hline Saint-louis & 0.81 & {$[0.43-1.50]$} & 0.494 \\
\hline Tambacounda* & 2.31 & {$[1.39-3.82]$} & 0.001 \\
\hline Kaolack* & 0.38 & {$[0.18-0.78]$} & 0.009 \\
\hline Thies* & 0.45 & {$[0.25-0.83]$} & 0.011 \\
\hline Louga* & 0.07 & {$[0.03-0.17]$} & 0.000 \\
\hline Fatick* & 0.27 & {$[0.13-0.54]$} & 0.000 \\
\hline kolda & 0.88 & {$[0.53-1.44]$} & 0.604 \\
\hline Matam* & 1.97 & {$[1.17-3.32]$} & 0.011 \\
\hline Kaffrine* & 0.25 & {$[0.11-0.58]$} & 0.001 \\
\hline Kedougou* & 2.76 & [1.42-5.39] & 0.003 \\
\hline Sedhiou & 1.16 & {$[0.67-2.01]$} & 0.600 \\
\hline \multicolumn{4}{|l|}{ Type of place residence } \\
\hline Urban & 1 & & \\
\hline Rural & 0.87 & {$[0.62-1.22]$} & 0.429 \\
\hline \multicolumn{4}{|l|}{ Religion } \\
\hline Muslim & 1 & & \\
\hline Christiane* & 0.06 & {$[0.02-0.14]$} & 0.000 \\
\hline no religion & 1 & & \\
\hline \multicolumn{4}{|l|}{ Ethnicity } \\
\hline Wolof & 1 & & \\
\hline Poular* & 83.22 & [34.09-203.11] & 0.000 \\
\hline serer & 0.76 & {$[0.22-2.64]$} & 0.668 \\
\hline mandingue/ soce* & 120.27 & [46.12-313.67] & 0.000 \\
\hline Diola* & 114.37 & [44.58-293.39] & 0.000 \\
\hline Soninke* & 85.05 & [30.07-240.53] & 0.000 \\
\hline senegalese ethnicity* & 65.47 & {$[24.72-173.36]$} & 0.000 \\
\hline not senegalese* & 141.09 & [49.35-403.39] & 0.000 \\
\hline \multicolumn{4}{|l|}{ sex of household head } \\
\hline male & 1 & & \\
\hline Female* & 0.76 & [0.59-0.97] & 0.029 \\
\hline
\end{tabular}




\section{Factors associated with FGM}

Protective factors for the occurrence of FGM were women's empowerment factors (high level of education of the woman (primary ajOR $=0.64[0.50-0.83]$ and secondary ajOR $=0.43$ $[0.32,0.57])$ and the fact that the head of the family was a woman ajOR (0.75 [0.59-0.97]); belonging to the central region of Senegal (Diourbel, Kaolack, Thiès, Louga and Fatcick) and Christian religion (ajOr=0.05 [0.02-0.13]). Risk factors for female genital mutilation in Senegal were ethnicity and belonging to certain regions in the northeast and southeast of Senegal (Tambacounda, Matam, Kedougou). (See Table 3).

\section{Discussion}

It is estimated that more than 200 million girls and women alive today have undergone female genital mutilation in countries where the practice is concentrated. In addition, an estimated 3 million girls are at risk of undergoing female genital mutilation each year [11]. In Senegal, the prevalence rate of FGM is $17.14 \%$ in 2018 . This high prevalence shown by our study is similar to other countries in Africa. In West Africa is $25.4 \%$ in 2017 [12]. For example, in Sudan the prevalence is $20 \%, 21.1 \%$ in Ghana $[13,14]$.

According to $\mathrm{WHO}, \mathrm{FGM} / \mathrm{C}$ is defined as "all procedures involving partial or total removal of the external female genitalia or other injury to the female genital organs for non-medical reasons." In the medical literature, four main types of FGM/C are recognized [15]:

Type I: excision of the clitoral hood with or without removal of parts or the entire clitoris (clitoridectomy);

Type II: excision of the clitoris together with parts or all of the labia minora;

Type III: excision of parts or the whole of the clitoris, labia minora and labia majora and stitching or narrowing of the introitus, with a very small outlet for passage of urine and menstruum. This is also known as infibulation;

Type IV: other harmful procedures to the female genitalia for non-medical purposes. Examples are-pricking, piercing, incising, scraping and cauterization. Others are hymenectomy, cutting of the vagina and introduction of corrosive substances or herbs into the vagina to cause bleeding or to tighten or narrow the vagina.

In Senegal, most women present as lesion flesh removed from genital area avec $60.96 \%$ which corresponds to type I and type II, $29.39 \%$ of women have Genital area just nicked without removing any flesh (Type IV) and $6.88 \%$ of women have an infibulation (Type III). The type of lesions identified by the DHS cannot be precise because it is based on a description of their anatomy by the respondents and not on direct observation by a health professional [16]. Depending on the type of mutilation, the genito-obstetrical complications are more or less serious but also the reconstruction is less possible [17]. In other countries of the world the most widespread types are type I mutilations, type III being found very rarely $[1,18]$.

Women who had heard of FGM represented $90.66 \%(8,535)$ of women. Fifteen-point thirty-nine percent $(15.39 \%)$ or 1,334 of the women think that it is a practice that should continue to be practiced and $80.59 \%$ (6,988 women) think that it should be stopped. Numerous health interventions and campaigns have been carried out in African countries to fight against FGM. These policies have led to a decline in the practice but above all to an increase in community awareness of these harmful practices [19]. This situation is not similar to that of countries in the sub-region where women still say they are not yet ready to abandon these practices [20]. Other studies have shown that information dissemination improves cognitions about FGM, but that the success of interventions depends on a range of other contextual factors [21].

Eleven-point fifty-two percent $(11.52 \%)$ or 999 women believe that FGM is a religiously recommended practice. Ninety-nine percent (993) of these women were Muslim $(p=0.0017)$. This is also the case in other countries where the prevalence of FGM is high and where one of the main reasons for the persistence of this practice is that communities believe that FGM is recommended by religion $[19,22]$. In Senegal, in some religious communities of the Pular ethnic group, despite laws that condemn these practices, they continue to be legitimized by religious arguments [23]. Our study showed that religion is indeed a factor associated with FGM practices.

The analysis of factors associated with FGM also showed that region of residence was a determinant of FGM. It was found that some regions, such as the Southeast, are strongly associated with FGM.

In our study, the protective factors for FGM are factors of women's empowerment. Thus, a high level of education would protect women from these practices (primary level oraj: 0.64 [0.50-0.82]; secondary level oraj: 0.43 [0.32-0.57]). Other studies had shown that FGM was less prevalent among educated women ( $p$ value $<0.001)[13,18]$. Empowerment factors were described as necessary to work on reducing FGM practices [24]. In the same register, our study showed that households headed by women were less likely to undergo FGM (ORaj: 0.76 [0.59-0.97]). In Guinea, the factors of empowerment of women through the strengthening of decision-making power allowed them to stand up against FGM practices [25]. Empowerment of women and girls was seen as an essential intervention to eradicate this practice [26].

\section{Limitations}

This study has some limitations. In particular, the analyses used cross-sectional data, so only associations and not causal relationships were established. This study could be complemented by a qualitative study to understand the contextual and socio-cultural factors that cause FGM practices to persist despite all the interventions implemented.

\section{Conclusion}

This study has shown that FGM practices are still persistent in Senegal. They are mostly practiced in certain regions of Senegal and by certain ethnic groups. Religious justification is still prevalent in the persistence of FGM. This study has highlighted that the empowerment of women would allow the fight against FGM. Health interventions should be multisectoral by involving the education sectors with a strong 
investment in girls' education and their retention in school. Households headed by women suffer less from this practice. This result shows the importance of women's decision-making autonomy, which could be an important lever on which policies could rely in the fight against FGM. In the future, this study could be complemented by qualitative studies that could explore the socio-cultural norms and social processes at work in these specific ethnic groups and regions of Senegal where high prevalence of FGM persists.

\section{References}

[1] Koski A, Heymann J. Thirty-year trends in the prevalence and severity of female genital mutilation: a comparison of 22 countries. BMJ Global Health: 8.

[2] Reisel D, Creighton SM. Long term health consequences of Female Genital Mutilation (FGM). Maturitas. janv 2015; 80 (1): 48-51.

[3] Berg RC, Underland V. The obstetric consequences of female genital mutilation/cutting: a systematic review and meta-analysis. Obstet Gynecol Int. 2013; 2013: 496564.

[4] Female genital mutilation [Internet]. [cité 26 avr 2021]. Disponible sur: https://www.who.int/news-room/fact-sheets/detail/female-geni tal-mutilation.

[5] Weltgesundheits organisation, éditeur. Eliminating female genital mutilation: an interagency statement; OHCHR, UNAIDS, UNDP, UNECA, UNESCO, UNFPA, UNHCR, UNIFEM, WHO. Geneva: World Health Organization; 2008. $40 \mathrm{p}$.

[6] SDG Indicators - SDG Indicators [Internet]. [cité 26 avr 2021]. Disponible sur: https://unstats.un.org/sdgs/metadata/?Text=\&Goal=5\&Target $=5.3$.

[7] Les mutilations sexuelles féminines (MSF). Division de l'Information, de la Documentation et des Recherches de l'Ofpra. 2019, 15p [Internet]. [cité 26 avr 2021]. Disponible sur:

https://ofpra.gouv.fr/sites/default/files/atoms/files/1905_sen mgf.pdf

[8] ICF International. 2012. Demographic and Health Survey Sampling and Household Listing Manual. MEASURE DHS, Calverton, Maryland, U.S.A.: ICF International. 98p.

[9] Croft, Trevor N., Aileen M. J. Marshall, Courtney K. Allen, et al. 2018. Guide to DHS Statistics. Rockville, Maryland, USA: ICF https://dhsprogram.com/data/Guide-to-DHS-Statistics/index.cfm.

[10] Collett D. Modelling Binary Data, Second Edition. CRC Press; 2002. $406 \mathrm{p}$.

[11] Prevalence of female genital mutilation [Internet]. [cité 28 avr 2021]. Disponible sur: https://www.who.int/teams/sexual-and-reproductive-health-an d-research/areas-of-work/female-genital-mutilation/prevalenc e-of-female-genital-mutilation.

[12] Kandala N-B, Ezejimofor MC, Uthman OA, Komba P. Secular trends in the prevalence of female genital mutilation/cutting among girls: a systematic analysis. BMJ
Global Health. 1 oct 2018; 3 (5): e000549.

[13] Satti A, Elmusharaf S, Bedri H, Idris T, Hashim MSK, Suliman GI, et al. Prevalence and determinants of the practice of genital mutilation of girls in Khartoum, Sudan. Annals of Tropical Paediatrics. 1 déc 2006; 26 (4): 303-10.

[14] Oduro AR, Ansah P, Hodgson A, Afful TM, Baiden F, Adongo P, et al. Trends in the prevalence of female genital muti-lation and its effect on delivery outcomes in the kassena-nankana district of northern Ghana. Ghana Medical Journal [Internet]. 2006 [cité 28 avr 2021]; 40 (3). Disponible sur: https://www.ajol.info/index.php/gmj/article/view/55258.

[15] Odukogbe A-TA, Afolabi BB, Bello OO, Adeyanju AS. Female genital mutilation/cutting in Africa. Transl Androl Urol. 2017; 6 (2): 138-48.

[16] Sénégal_-_2018_01.pdf [Internet]. [cité 28 avr 2021]. Disponible - sur: https://www.rhsupplies.org/uploads/tx_rhscpublications/S\%C 3\%A9n\%C3\%A9gal_-_2018_01.pdf.

[17] Puppo V. Female genital mutilation and cutting: An anatomical review and alternative rites. Clin Anat. janv 2017; 30 (1): 81-8.

[18] Al Awar S, Al-Jefout M, Osman N, Balayah Z, Al Kindi N, Ucenic T. Prevalence, knowledge, attitude and practices of female genital mutilation and cutting (FGM/C) among United Arab Emirates population. BMC Womens Health. 22 avr 2020; 20 (1): 79.

[19] Awolola OO, Ilupeju NA. Female genital mutilation; culture, religion, and medicalization, where do we direct our searchlights for it eradication: Nigeria as a case study. Tzu Chi Med J. 2019; 31 (1): 1-4.

[20] Dicko-Traoré F, Diakité FL, Diakité AA, Konaté D, Keïta JT, Traoré $\mathrm{F}$, et al. Connaisssances, attitudes et pratiques des mères relatives a l'excision a bamako. Mali Med. 31 mars 2014; 30-5.

[21] Berg RC, Denison E. Interventions to reduce the prevalence of female genital mutilation/cutting in African countries. Campbell Systematic Reviews. 2012; 8 (1): 1-155.

[22] Shabila NP, Ahmed HM, Safari K. Knowledge, attitude, and experience of health professionals of female genital mutilation (FGM): A qualitative study in Iraqi Kurdistan Region. Health Care Women Int. nov 2017; 38 (11): 1202-18.

[23] Sylla PS. Interdiction de l'excision au Sénégal: pour comprendre les raisons de l'inefficacité de la loi. Centre Interdisciplinaire d'Études et de Recherche de la Vallée (CIERVAL), Université Gaston Berger. 2002; 18p.

[24] Diop NJ, Askew I. The Effectiveness of a Community-based Education Program on Abandoning Female Genital Mutilation/Cutting in Senegal. Studies in Family Planning. 2009; 40 (4): 307-18.

[25] Doucet M-H, Delamou A, Manet H, Groleau D. Beyond will: the empowerment conditions needed to abandon female genital mutilation in Conakry (Guinea), a focused ethnography. Reprod Health. déc 2020; 17 (1): 61.

[26] Williams-Breault BD. Eradicating Female Genital Mutilation/Cutting. Health Hum Rights. déc 2018; 20 (2): 223-33. 